\title{
Distribution and conservation status of the endemic Chinese mountain cat Felis bieti
}

\author{
Li He, Rosa García-Perea, Ming Li and Fuwen Wei
}

\begin{abstract}
Records of the Vulnerable Chinese mountain cat Felis bieti are known from the eastern border of the Tibetan Plateau, mostly from Qinghai province, but also from other areas further north, east and north-west. Disagreement regarding the reliability of some records has led to uncertainty about the species' distribution. In order to obtain information about its current distribution and status we conducted surveys in various Chinese provinces and evaluated former records and specimens. Forty-five specimens and living individuals were examined, and 189 records were gathered from local sources. Our data confirm that this cat is endemic to China, and
\end{abstract}

occurs in montane forest edge, alpine shrubland and meadow habitats. At present it is confined to the provinces of eastern Qinghai and northern Sichuan. Its wild populations are facing a number of threats and environmental pressures such as poaching, use of chemical rodenticides, and environmental changes. We recommend moving this species to Category I of Chinese law, enforcement of its protection in reserves, and the establishment of new reserves, specifically for this species, in areas in which it is currently unprotected.

Keywords China, Chinese mountain cat, distribution, Felis bieti, Qinghai, Sichuan.

\section{Introduction}

The Chinese mountain cat Felis bieti (Plate 1) is one of the most poorly known living felids. It has been reported to occur in several Chinese provinces, including Qinghai, Sichuan, Gansu, Ningxia, Inner Mongolia, Xinjiang, Tibet and Shaanxi (Jacobi, 1922; Allen, 1938; Pocock, 1951; Gao, 1987). Although the records from Ningxia and Shaanxi appear to be misidentifications (Groves, 1980) and were accepted as such by Nowell \& Jackson (1996), the species is still described as having a very wide range in a recent book on the distribution of Chinese mammals (Zhang, 1997).

One of the problems is the difficulty of identification. This cat is almost unknown to Chinese scientists, and the few specimens kept at Chinese institutions are mostly misidentified. A similar confusion applies to local hunters, who do not know what species they are dealing with when they capture the animal (pers. obs.). Fur traders are probably more familiar with the identification of the species, but they do not have an interest in the geographical origin of any pelts that they receive. Therefore it is common to find incorrect information in the local

Li He, Ming Li and Fuwen Wei (Corresponding author) Institute of Zoology, Chinese Academy of Sciences, Haidian, Beijing, 100080, China. E-mail: weifw@panda.ioz.ac.cn

Rosa García-Perea Museo Nacional de Ciencias Naturales, C/J. Gutierrez Abascal 2, Madrid 28006, Spain.

Received 8 October 2002. Revision requested 21 March 2003. Accepted 20 June 2003. literature, with the species often confused with manul Otocolobus manul, Asiatic wildcats of the Felis silvestris ornata group, or lynx Lynx lynx (e.g. Wang, 1990, 1991). Thus any information on the distribution and occurrence of the species requires careful evaluation of the source. However, there is little available published information. Besides old descriptions of $F$. bieti and two potential subspecies, F. bieti chutuchta and F. bieti vellerosa, Lönnberg (1926), Pocock (1951), Haltenorth (1953) and Groves (1980) made valuable descriptions and revisions of material kept at European museums. The only available data on the biology of the species was provided by Liao (1988). In order to identify potential threats, assess conservation status and plan management programmes, detailed information about the species' distribution and status in the wild is required. Our purpose in this paper is to address this problem by collating all of the information available on the species (priority project 76 of Wild Cats, Status, Survey and Conservation Action Plan; Nowell and Jackson, 1996).

\section{Methods}

This study was conducted in 2000 and 2001. Our main goals were to obtain distribution records from both Chinese and foreign literature, examine specimens kept in Chinse institutions, living individuals in zoos, animals captured by local hunters or observed by wildlife officers, and skins found in fur markets. We focused on making correct identifications of specimens and living 


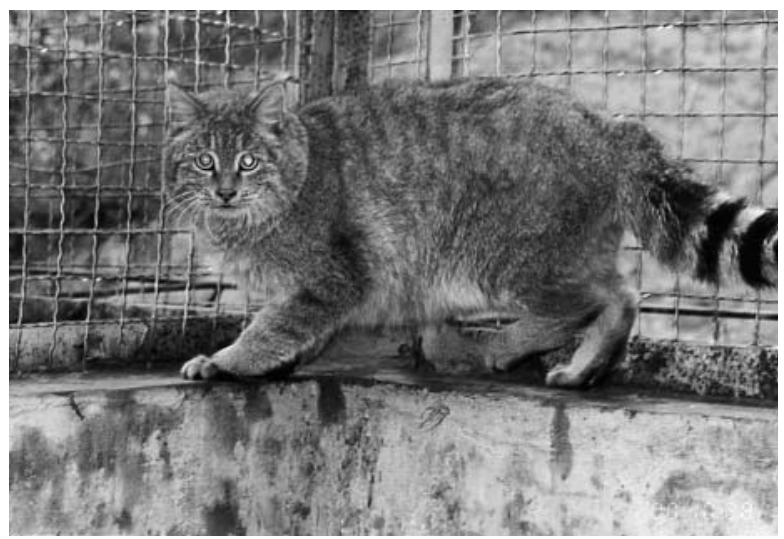

Plate 1 A Chinese mountain cat Felis bieti kept at the Wildlife Rescue Center, Xining, China.

individuals, and assessing the accuracy of each bibliographic or verbal record.

In external appearance $F$. bieti can be confused with manul, from which it can be distinguished by its larger size, moderately developed ear tufts, uniform pale brown coat and long, conspicuously ringed tail (Plate 1); manul has ears without tufts, a grayish colour and a short tail with a dark tip. Asiatic wildcat has a slimmer build than F. bieti, a light brown or grey coloration with dark spots and a slim tail. Lynx has a very short tail, long ear tufts, and is larger in size (Groves, 1980; Mallon, 2002). Skulls of $F$. bieti were identified following the description given by Lönnberg (1926); they can be distinguished by the inflated tympanic bulla (although it is not as well developed as that of manul), a mesial ridge on the basisphenoid and presphenoid bones, and the absence of a metaconid in the lower carnassial $\mathrm{m} 1$.

\section{Results}

A total of 45 specimens and living individuals formerly identified as F. bieti were examined from Beijing, Qinghai, Gansu, Sichuan, Ningxia, Xinjiang and Inner Mongolia (Table 1). In addition, 168 records were examined from the literature, and 21 records were obtained from local hunters, fur traders and wildlife officers. Out of 45 specimens examined, 40 were identified as $F$. bieti (30 specimens and 10 individuals), four as belonging to the $F$. silvestris ornata group (in Gansu and Ningxia), and one as O. manul (in Xinjiang). Although specimens and living individuals have been reported from Qinghai, Sichuan, Gansu, Ningxia, Xinjiang and Inner Mongolia, the present range of $F$. biet $i$ is restricted to the eastern half of Qinghai and north-western Sichuan (Fig. 1).

Qinghai. The cat is most frequently found in this province, where its range covers 23 counties (Table 1 ). Since 1973, 44 living animals, of which 10 are still alive, have been captured and kept in captivity at Xining Zoo,
Beijing Zoo and Xining Wildlife Rescue Center (Liao, 1985; NWIB, 1989; Table 1). Of these, 21 individuals were captured from Huangzhong, Huangyuan, Menyuan, Qilian, Tongren and Dulan, the localities in which F. bieti was most commonly found (Liao, 1988).

Sichuan. F. bieti occurs in north-western Sichuan (=Szechwan) (Hu \& Wang, 1984). Its range includes seven counties: Songpan (=Sungpan), Garze, Dawu, Dege, Zamtang, Kangding and Jiuzhaigou. Most of the specimens kept in Europe were collected from this province (Table 1). The type specimens were collected from the vicinity of Tatsienlu (=Kangding) and Tongolo (a location that we are unable to identify) (MilneEdwards, 1892). Jacobi (1922) described two skins collected by the Weigold Expedition from Songpan. Matschie (1908) recorded a skin collected by the Filchner Expedition from Kweito (another location that we are unable to identify), in the extreme west of Sichuan, not far south of the type locality of Felis pallida (a synonym of F. bieti). Weigold secured two specimens in 1922 from the wooded mountains of Wassulan (a further location that we are unable to identify), one caught in a snare and the other purchased in a store (Allen, 1938). In 2001 we found 50 skins on sale at Songpan and Jiuzhaigou markets; the skins were confiscated and are now kept at Sichuan Normal College, the Institute of Zoology, Chinese Academy of Sciences, and Sichuan Forestry Bureau. During our own survey in Kangding we could not locate any recent records of the species.

Gansu F. bieti was reportedly found in southern Gansu (=Kansu). Twelve specimens assigned to this species (Allen, 1938; Groves, 1980), kept at the St Petersburg and Stockholm Museums, were collected from Minshan Mountains, western Gansu and southern Tetung (or Tatung $=$ Datonghe) Mountains, but the first locality is along the border of Qinghai and Gansu, and the latter locality corresponds to the Datonghe Mountains of Qinghai province. Wang (1991) identified two individuals as F. bieti that were captured in a suburb of Lanzhou. However, we checked the specimens and identified them as belonging to the F. silvestris ornata group. Liu (2001) reported the species in Dunhuang Natural Reserve but his information, taken from old books, is unreliable. Besides specimens in foreign museums, no specimens from Gansu are known to Chinese researchers.

Ningxia. F. bieti was reported from the north-west of this province. Birula (1917) described one specimen, collected by Kozlov in 1908 at Goizso (from Gobi of 'Southern Mongolia') as a new species, Felis chutuchta. This locality is actually in north-western Ningxia (Gao, 1987). However, Haltenorth (1953) and Groves (1980) concluded that this specimen was $F$. silvestris ornata. Whether or not $F$. bieti occurs in this Province is as yet unresolved, given the inconsistency of morphological information 
Table 1 The Province, reference number and locality (given in Fig. 1 where available), number and type of records including institution where relevant, and the reference or source of confirmed, misidentified and unreliable records of Felis bieti examined in this study, including specimens.

\begin{tabular}{|c|c|c|c|}
\hline Province & Ref. no. in Fig. 1, locality & $\begin{array}{l}\text { Number and type of } \\
\text { record }(\mathrm{s})^{1}, \text { Institution }{ }^{2} \text { (notes) }\end{array}$ & Reference or source \\
\hline \multicolumn{4}{|c|}{ Confirmed records of Felis bieti } \\
\hline Qinghai & 1, Gangca & $1 \mathrm{~L}, \mathrm{XNZ}$ (died) & Liao, 1985 \\
\hline Qinghai & 2, Menyuan & $3 \mathrm{~L}, \mathrm{XNZ}$ ( died) & Liao, 1985 \\
\hline Qinghai & 3, Huzhu & $1 \mathrm{~L}, \mathrm{XNZ}$ (died) & Liao, 1985 \\
\hline Qinghai & 4, Ledu & $2 \mathrm{~L}, \mathrm{XNZ}$ (died) & Liao, 1985 \\
\hline Qinghai & 5, Minhe & $\mathrm{R}$ & NWBI, 1989; this study \\
\hline Qinghai & 6, Datong & $1 \mathrm{~L}, \mathrm{XNZ}$ (died) & Liao, 1985 \\
\hline Qinghai & 7, Gonghe & $\mathrm{R}$ & NWBI, 1989; this study \\
\hline Qinghai & 8, Huangyuan & $5 \mathrm{~L}, \mathrm{XNZ}$ (died) & Liao, 1985 \\
\hline Qinghai & 9, Haiyan & $\mathrm{R}$ & NWBI, 1989; this study \\
\hline Qinghai & 10, Huangzhong & $5 \mathrm{~L}, \mathrm{XNZ}$ (died) & Liao, 1985 \\
\hline Qinghai & 11, Zekog & $1 \mathrm{~L}, \mathrm{XNZ}$ (died) & Liao, 1985 \\
\hline Qinghai & 12 , Tongren & $2 \mathrm{~L}, \mathrm{XNZ}$ (died) & Liao, 1985 \\
\hline Qinghai & 13, Jianca & $\mathrm{R}$ & Liao, 1988; this study \\
\hline Qinghai & 14, Qilian & $5 \mathrm{~L}, \mathrm{XNZ}$ (died) & Liao, 1985 \\
\hline Qinghai & 15, Tianjun & $1 \mathrm{~L}, \mathrm{XNZ}$ (died) & Liao, 1985 \\
\hline Qinghai & 16, Ulan & $1 \mathrm{~L}, \mathrm{XNZ}$ (died) & Liao, 1985 \\
\hline Qinghai & 17, Dulan & $1 \mathrm{~L}, \mathrm{XNZ}$ (died) & Liao, 1985 \\
\hline Qinghai & 18, Xinghai & $1 \mathrm{~L}, \mathrm{XNZ}$ (died) & Liao, 1985 \\
\hline Qinghai & 19, Madoi & $1 \mathrm{~L}, \mathrm{XNZ}$ (died) & Liao, 1985 \\
\hline Qinghai & 20, Yushu & $\mathrm{R}$ & Liao, 1988; this study \\
\hline Qinghai & 21, Golmud & $1 \mathrm{~L}, \mathrm{XNZ}$ (died) & Liao, 1985 \\
\hline Qinghai & 22, Nangqen & $1 \mathrm{~L}, \mathrm{XNZ}$ (died) & Liao, 1985 \\
\hline Qinghai & Xining & $1 \mathrm{~L}, \mathrm{XNZ}$ (died) & Liao, 1985 \\
\hline Qinghai & Vicinity of Xining & $16 \mathrm{SN}, \mathrm{NWIB}$ & This study \\
\hline Qinghai & Vicinity of Xining & $4 \mathrm{~L}, 1 \mathrm{SK}+\mathrm{SN}, 1 \mathrm{SN}, \mathrm{WRCX}$ & This study \\
\hline Qinghai & Vicinity of Xining & $4 \mathrm{~L}, \mathrm{XNZ}$ & This study \\
\hline Qinghai & Vicinity of Xining & $2 \mathrm{~L}, \mathrm{BJZ}$ & This study \\
\hline Qinghai & 23, S. Tetung (= Datonghe) Mts & $8 \mathrm{SN}, \mathrm{ZMAS}$ & $\begin{array}{l}\text { Lönnberg, 1926; Allen, 1938; } \\
\text { Haltenorth, 1953; Groves, } 1980\end{array}$ \\
\hline Qinghai & S. Tetung (= Datonghe) Mts & $2 \mathrm{SN}, \mathrm{SM}$ & Haltenorth, 1953; Groves, 1980 \\
\hline Probably Qinghai & Labeled 'Tibet' & $2 \mathrm{SN}, \mathrm{ZM}$ & Groves, 1980 \\
\hline Qinghai/Gansu & 24, Minshan, W. Kansu (= Gansu) & $1 \mathrm{SK}+\mathrm{SN}, \mathrm{SM}$ & Haltenorth, 1953; Groves, 1980 \\
\hline Sichuan & 25, Jiuzhaigou & $2 \mathrm{SK}, 4 \mathrm{SN}, \mathrm{SNCN}$ & This study \\
\hline Sichuan & 26, Songpan & $1 \mathrm{SN}, \mathrm{IZB}$ & This study \\
\hline Sichuan & Songpan & $1 \mathrm{SN}, \mathrm{CDRBGPB}$ & This study \\
\hline Sichuan & Sungpan (=Songpan) & $1 \mathrm{SN}, \mathrm{DM}$ (now destroyed) & $\begin{array}{l}\text { Jocobi, 1922; Haltenorth, 1953; } \\
\text { Groves, } 1980\end{array}$ \\
\hline Sichuan & Songpan & $1 \mathrm{SN}, \mathrm{RVNH}$ (from DM) & Groves, 1980 \\
\hline Sichuan & 27, Garze & $\mathrm{R}$ & Hu \& Wang, 1984; this study \\
\hline Sichuan & 28, Dawu & $\mathrm{R}$ & Hu \& Wang, 1984; this study \\
\hline Sichuan & 29, Dege & $\mathrm{R}$ & Hu \& Wang, 1984; this study \\
\hline Sichuan & 30, Zamtang & $\mathrm{R}$ & Hu \& Wang, 1984; this study \\
\hline Sichuan & $\begin{array}{l}\text { 31, Tatsienlu (=Kangding), } \\
\text { Tongolo (unidentified location) }\end{array}$ & $2 \mathrm{SN}, 1 \mathrm{SK}, \mathrm{MHNP}$ & $\begin{array}{l}\text { Allen, 1938; Haltenorth, 1953; } \\
\text { Groves, } 1980\end{array}$ \\
\hline Sichuan & $\begin{array}{l}\text { Kweito, W. Sicuani } \\
\text { (not found at present) }\end{array}$ & $\begin{array}{l}1 \mathrm{SN}, \mathrm{ZSM} \\
\text { (no longer extant by 1953) }\end{array}$ & $\begin{array}{l}\text { Matschie, 1908; Allen, 1938; } \\
\text { Haltenorth, 1953; Groves, } 1980\end{array}$ \\
\hline Sichuan & Wassuland (unidentified location) & $2 \mathrm{SN}$, ? & Weigold, 1923; Allen, 1938 \\
\hline Possibly Inner & Purchased in Inner Mongolia, & $4 \mathrm{SN}, \mathrm{IZB}$ & This study \\
\hline Mongolia, Ningxia & Ningxia, and Beijing & & \\
\hline \multicolumn{4}{|c|}{ Records of $F$. silvestris $(F s)$ or O. manul $(\mathrm{Om})$, misidentified as Felis bieti } \\
\hline Gansu & 32, Lanzhou & $1 \mathrm{SK}+\mathrm{SN}, \mathrm{LMNH}(F s)$ & This study; Wang 1991 \\
\hline Gansu & 32, Lanzhou, captured in 1979 & $1 \mathrm{~L}, \mathrm{XAZ}(F s$, died $)$ & This study; Wang, 1991 \\
\hline Ningxia & 33, Zhongwei Shapotou Reserve & $2 \mathrm{SN}, \mathrm{ZSR}(F s)$ & This study \\
\hline Ningxia & $\begin{array}{l}\text { Gobi of Southern Mongolia, in } \\
\text { Goizso (present Ningxia) }\end{array}$ & $1 \mathrm{SK}+\mathrm{SN}, \mathrm{ZMAS}(F s)$ & Birula, 1917; Gao, 1987 \\
\hline Shaanxi & 34, Yulinfu (= Yulin), Ordo & $1 \mathrm{SN}, \mathrm{BM}(F s)$ & Pocock, 1943; Groves, 1980 \\
\hline Xinjiang & 35, Qitai & $1 \mathrm{SK}, \mathrm{XJU}(\mathrm{Om})$ & This study \\
\hline
\end{tabular}


Table 1 (Continued)

\begin{tabular}{|c|c|c|c|}
\hline Province & Ref. no. in Fig. 1, locality & $\begin{array}{l}\text { Number and type of } \\
\operatorname{record}(s)^{1}, \text { Institution }{ }^{2} \text { (notes) }\end{array}$ & Reference or source \\
\hline \multicolumn{4}{|c|}{ Unreliable records of Felis bieti } \\
\hline Gansu & 36, Jiuquan & $\mathrm{R}$ & Liu, 2001 \\
\hline Gansu & 37, Aksay & $\mathrm{R}$ & Wang, 1991 \\
\hline Gansu & 38, Subei & $\mathrm{R}$ & Liu, 2001 \\
\hline Gansu & 39, Dunhuang & $\mathrm{R}$ & Liu, 2001 \\
\hline Inner Mongolia & 40, Alxa Zuoqi & $\mathrm{R}$ & Wang et al., 1977; this study \\
\hline \multirow[t]{3}{*}{ Xinjiang } & 41, Artux & \multirow[t]{3}{*}{$\mathrm{R}$} & Xinjiang Expedition Team of \\
\hline & 42, Wuqia & & Chinese Academy of Sciences, \\
\hline & 43, Baicheng & & 1960 ; this study \\
\hline \multirow[t]{3}{*}{ Xinjiang } & 44, Yanqi & \multirow[t]{3}{*}{$\mathrm{R}$} & Xinjiang Expedition Team of \\
\hline & 45, Markit & & Chinese Academy of Sciences, \\
\hline & 46, Yecheng & & 1960; this study \\
\hline \multirow[t]{3}{*}{ Xinjiang } & 47, Yutian & \multirow[t]{3}{*}{$\mathrm{R}$} & Xinjiang Expedition Team of \\
\hline & 48, Qiemo & & Chinese Academy of Sciences, \\
\hline & 49, Hami & & 1960 ; this study \\
\hline Tibet & 50, Nagqu & $\mathrm{R}$ & Yin \& Liu, 1993; this study \\
\hline Tibet & 51, Ngari & $\mathrm{R}$ & Yin \& Liu, 1993; this study \\
\hline Tibet & 52, Dengqen & $\mathrm{R}$ & Yin \& Liu, 1993; this study \\
\hline Tibet & 53, Baqen & $\mathrm{R}$ & Yin \& Liu, 1993; this study \\
\hline Tibet & 54, Biru & $\mathrm{R}$ & Yin \& Liu, 1993; this study \\
\hline Tibet & 55, Sog Xian & $\mathrm{R}$ & Yin \& Liu, 1993; this study \\
\hline Xinjiang & Pamir and Kunlun Mts & $\mathrm{R}$ & Wang \& Wang, 1986; this study \\
\hline
\end{tabular}

${ }^{1}$ Skulls (SK), skins (SN), living individuals (L), and reports (R) from the literature, or obtained from interviews (this study).

${ }^{2}$ Institutions where specimens or living individuals were examined, or where specimens recorded in the literature were kept. China: IZB (Institute of Zoology, Beijing); NWIB (Northwest Plateau Institute of Biology, Xining, Qinghai); WRCX (Wildlife Rescue Centre, Xining, Qinghai); XNZ (Xining Zoo, Xining, Qinghai); XAZ (Xi'an Zoo, Xi'an, Shaanxi); LMNH (Lanzhou Museum of Natural History, Lanzhou, Gansu); SNCN (Sichuan Normal College, Nanchong, Sichuan); CDRBGPB (Chengdu Research Base of Giant Panda Breeding, Chengdu, Sichuan); BJZ (Beijing Zoo, Beijing); ZSR (Zhongwei Shapotou Reserve, Ningxia); XJU (Xinjiang University, Urumqi, Xinjiang). Europe: MHNP (Museum National d'Histoire Naturelle, Paris, France); DM (Dresden Museum, Dresden, Germany); RVNH (Rijksmuseum voor Natuurlijke Historie, Leiden, The Netherlands); ZSM (Zoologisches Staatssamlung Munchen, Munich, Germany); SM (Stockholm Museum, Stockholm, Sweden); ZM (Zoologisches Museum, Berlin, Germany); BM (Natural History Museum, London, UK); ZMAS (Zoological Museum of the Academy of Science, St Petersburg, Russia).

for cats recorded there (Ognev, 1935; Pocock, 1951; Haltenorth, 1953; Groves, 1980). In 1986 two living cats were taken by hunters in Zhongwei Shapotou Reserve and identified as F. bieti chutuchta (Wang, 1990). We checked these specimens and found them to be F. silvestris ornata. Finally, although one skin of F. bieti kept at the Institute of Zoology, Chinese Academy of Sciences, was purchased in this province in the 1970s, its precise locality is not recorded. Thus there are no reliable records from this Province.

Shaanxi. Pocock (1943) described a new subspecies, F. bieti vellerosa, from a skin kept at The Natural History Museum, London, collected from Yulin (=Yulinfu, Ordos), Shaanxi (Gao, 1987). However, Groves (1980) rechecked this specimen and identified it as a domestic cat. Other than this record, there have been no reports or collections of F. bieti from this Province.

Xinjiang. The survey conducted in the 1950s by the Chinese Academy of Sciences reported sightings in nine counties (Xinjiang Expedition Team of Chinese Academy of Sciences, 1960; Table 1), but no specimens were collected. Wang \& Wang (1986) reported that F. bieti may occur in the desert mountains of Xinjiang (the Pamir and Kunlun Mountains), but the reports have not yet been confirmed (Achuff \& Petocz, 1988). We located only one possible specimen, collected from Qitai County and kept in Xinjiang University (D.M. Zhang, pers. comm., 2001) but upon examination we concluded it was $O$. manul. Thus there are no reliable records from this Province.

Inner Mongolia. The subspecies F. bieti chutuchta was originally described after a specimen collected in this Province but, as confirmed by Gao (1987), it was from north-western Ningxia. Although Wang et al. (1977) reported its occurrence in Alxa Zuoqi, this record is not reliable because Wang $(1990,1991)$ twice misidentified F. silvestris as F. bieti. Although one skin of F. bieti, in the Institute of Zoology, Chinese Academy of Sciences, was purchased in this province in the 1970s, its precise locality is not recorded. We were not able to find any further information concerning the past or present occurrence of F. bieti in this Province.

Tibet. Groves (1980) reported that two skins kept at the Zoologisches Museum, Berlin, were labelled Tibet. As the name Tibet was applied to the whole Tibetan 


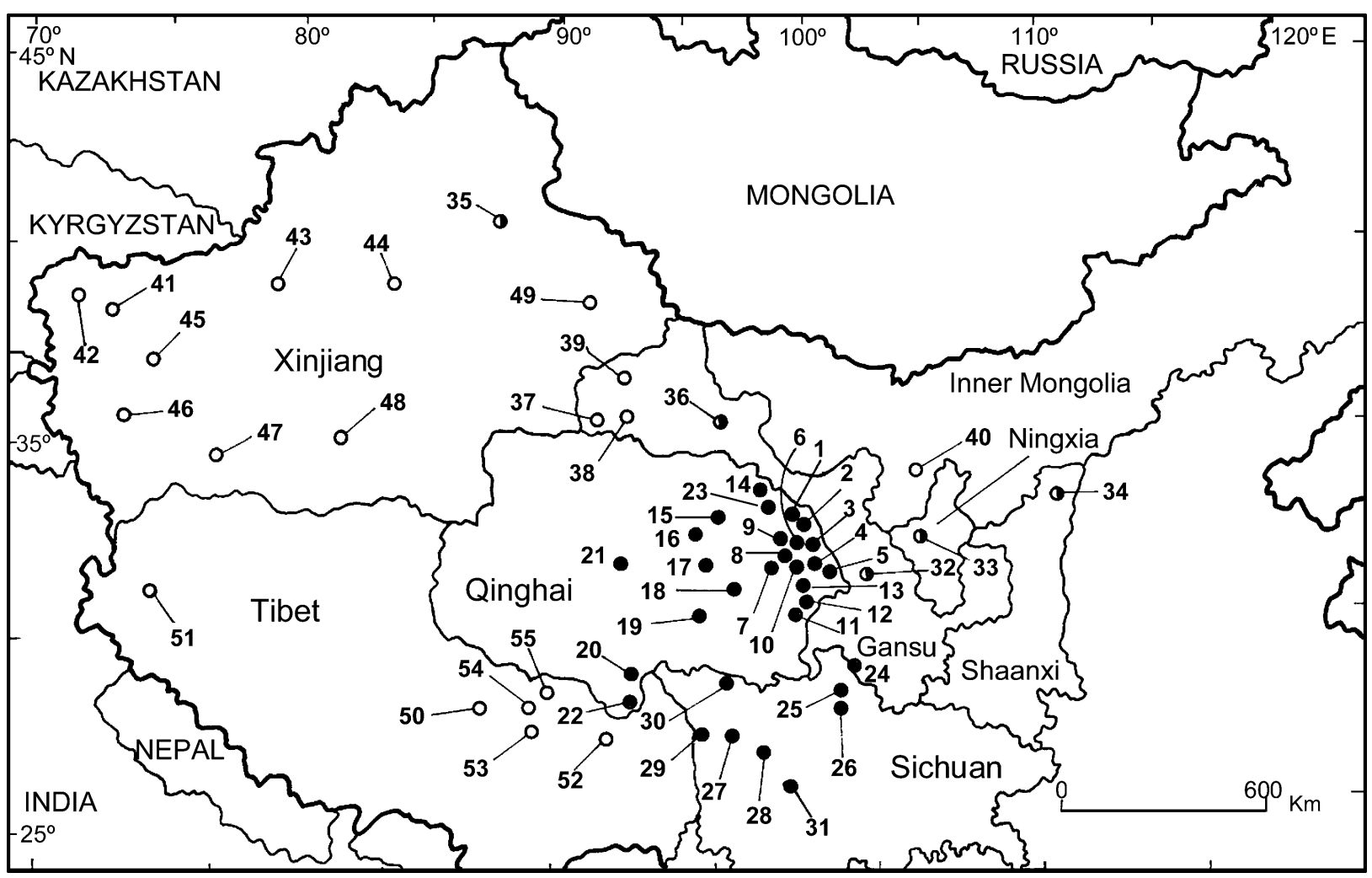

Fig. 1 Records attributed to the Chinese mountain cat Felis bieti. Black circles, confirmed records; white circles, unreliable records; black and white circles, misidentified records.

Plateau in the early 20th century and the collector, Tafel, travelled through what is now Qinghai province, Groves suggested that the skins came from the eastern slopes of the highlands of that Province rather than from the area now referred to as Tibet. We did not find any records in the Chinese literature, and no specimens have been collected, although the Chinese Academy of Sciences conducted a large- scale, long-term survey in the area (Feng et al., 1986). An investigation conducted by the Tibet Forestry Bureau in the 1990s suggested that F. biet $i$ occurred at Nagqu, Ngari, Dengqen, Baqen, Biru and Sog Xian (Yin \& Liu, 1993) but given the lack of either earlier or recent records, we consider this information to be unreliable.

This cat was previously called the pale desert cat and Chinese desert cat by Allen (1938) and Ellerman \& Morrison-Scott (1951), respectively, based on its supposed occurrence in desertic habitats. However, after Groves (1980) revised the records assigned to this species he found it to be a species of montane woodlands and thickets, and suggested the more appropriate name Chinese mountain cat. F. bieti has also been seen in the grassland meadows at Haibei Station of the Chinese Academy of Sciences, Qinghai (W.H. Wei, pers comm., 2001), and Liao (1988) reported it to be characteristic of alpine meadow, alpine shrubland, coniferous forest edges, grassland meadows, semi-desert and desert areas, and loess hill steppes, at elevations of 2,800-4,100 $\mathrm{m}$ in Qinghai. Of these, the first four constitute its principal habitat, in which shrub species such as Salix oritrepha, Dasiphora fruticosa, Rhododendron spp., and coniferous species such as Picea asperata and Sabina prezewalskii are dominant. In these habitats $F$. bieti feeds mainly on pikas Ochotona cansus, O. curzoniae and O. daurica, hares Lepus oiostolus, voles Microtus oeconomus and zokors Myospalax baileyi. In Sichuan, Weigold captured one F. bieti, and almost captured a second, in wooded mountains of Songpan at 3,000 $\mathrm{m}$ (Jacobi, 1922). Collating the available information it appears that $F$. bieti inhabits forest edges, alpine shrub land and meadows over altitudes of 2,500-5,000 m; it may also occur in desert or semi-desert habitats, but this is yet to be confirmed.

\section{Discussion}

The Chinese mountain was categorized by Nowell \& Jackson (1996) as one of the five felid species most vulnerable to extinction. It is listed on Appendix II of CITES and is categorized as Vulnerable on the 2002 IUCN Red List. At the national level, it is regarded as a rare animal, categorized as a Category II species, and protected by various Chinese laws, such as the Wild 
Animal Protection Law and the Forestry Law. Our results confirm that this cat occurs only in China, and its present range, eastern Qinghai and northern Sichuan, seems to be a relict of its former range. Some former records are unreliable and some confirm that populations, such as in Kangding, have become extinct. Wild populations of $F$. biet $i$ are facing a number of threats and environmental pressures.

Firstly, hunting for pelts is one of the main threats, even after it was included in the National Wild Animal Protection List in 1988. Nowell \& Jackson (1996) reported trade in the species' fur in southern China in the 1990s. During our visits to Songpan and Jiuzhaigou we found pelts, and also jackets made from F. bieti, for sale.

Secondly, extensive use of rodenticides is another threat. Since the 1950s large-scale poisoning campaigns have been conducted in the main range (Qinghai and Sichuan) of the species, to control populations of rodents and lagomorphs. From the 1950s to the late 1990s $>208,000$ ha of meadows were treated with rodenticides in Qinghai (Fan et al., 1999). The Chinese Government plans to control so-called rodent pests in c.7,200,000 ha of the alpine meadows of the Tibetan plateau, such as in Qinghai, Sichuan, Gansu and Tibet, over the next 5 years (W. Zhong, pers. comm.). During these campaigns several rodenticides have been used, such as zinc phosphide from the 1970s to the mid-1980s, and bromadiolone, cumatetralyl, diphacinone-Na and chlorophacinone from the mid-1980s to the 1990s (W. Zhong, pers. comm.). Although these chemicals can reduce the density of rodents, they also cause environmental pollution and secondary poisoning of predators such as Chinese mountain cats (Zhong et al., 1999). Although other methods of pest control have been introduced (Zhang \& Wang, 1998; Zhong et al., 1999), chemical rodenticides are still being used.

Thirdly, the Government's Western China Development will probably involve environmental changes and alteration of natural habitats within the range of $F$. bieti.

Although three reserves have been created within the present range of F. bieti (Sanjiangyuan Reserve, 15,800,000 ha, and Qinghai Lake Reserve, 495,200 ha, in Qinghai, and Jiuzhaigou Reserve, 64,300 ha, in Sichuan), most of its range is not protected. In addition, poaching, rodenticide use and environmental changes continue throughout its range. In 1992 the Cat Specialist Group recommended the inclusion of $F$. biet $i$ as a Category I species under Chinese law (Nowell \& Jackson, 1996), but this has not yet been considered by the Chinese government. Based on our results, we also recommend moving this species to Category I of Chinese law, enforcement of its protection in reserves, and the establishment of new reserves, specifically for this species, in areas in which it is currently unprotected. Finally, although no population surveys of the species have yet been carried out, the categorization of F. bieti as Vulnerable (IUCN, 2002) based on criterion $\mathrm{C} 2 \mathrm{a}(\mathrm{i})$, i.e. population size estimated to be $<10,000$ mature individuals $(C)$, with a continuing decline in numbers (2), and with no subpopulation estimated to contain $>1000$ mature individuals $(\mathrm{a}(\mathrm{I}))$, appears to be appropriate.

\section{Acknowledgements}

This study was supported by Cat Action Treasury (Kristin Nowell) through a grant to RGP (from E.J. Tim and Laura Enander Harris Family Foundation) and the National Science Fund for Distinguished Young Scholars (No. 30125006) to FWW. J. Gisbert participated in the field study in 2001 and drew Fig. 1. We thank Peter Jackson and Kristin Nowell for their cooperation in the information search, and Colin Groves for confirming identification, through pictures, of some specimens. We are indebted to officials, wildlife authorities and zookeepers from different provinces, and grateful to $\mathrm{Hu}$ Jinchu, Liao Yanfa, Liu Naifa, Zhang Chunguang, Wei Wanhong, Wu Guosheng, Zhang Yingmei, Zhang Daming, Wu Xianzhi, and a long list of technicians who kindly assisted us. This article also benefited from the useful comments of two anonymous reviewers.

\section{References}

Allen, G.M. (1938) The Mammals of China and Mongolia. Natural History of Central Asia, Vol. XI. American Museum of Natural History, New York, USA.

Achuff, P.L. \& Petocz, R. (1988) Preliminary resource inventory of the Arjin Mountains Nature Reserve, Xinjiang, People Republic of China. Unpublished Report, WWF, Gland, Switzerland.

Birula, A. (1917) De Felibus asiaticus duabus novis. Annuaire du Musée Zoologique de l'Academie des Sciences, Petrograd, (Nouvelles et Faits divers), 21, 1-2.

Ellerman, J.R. \& Morrison-Scott, T.C.S. (1951) Checklist of Palaearctic and Indian Mammals 1758 to 1946. British Museum (Natural History) Trustees, London, UK.

Fan, N.C., Zhou, W.Y., Wei, W.H., Wang, Q.Y. \& Jiang, Y.J. (1999) Rodent management in the Qinghai-Tibet alpine meadow ecosystem. In Ecologically-based Management of Rodent Pests (eds G. R. Singleton, L.A. Hinds, H. Leirs \& Z.B. Zhang), pp. 285-304. Australian Centre for International Agricultural Research Monograph, 59.

Feng, Z., Cai, G. \& Zheng, C. (1986) Mammals of Tibet. Science Press, Beijing, China [in Chinese].

Gao, Y. (1987) Fauna Sinica, Mammalia, Vol.8, Carnivora. Science Press, Beijing, China [in Chinese].

Groves, C.P. (1980) The Chinese mountain cat (Felis bieti). Carnivore, 3, 35-41.

Hu, J. \& Wang, Y. (eds) (1984) Sichuan Fauna Economica, Vol. 2 (Mammals). Sichuan Publishing House of Science and Technology, Chengdu, China [in Chinese].

Haltenorth, Th. (1953) Die Wildkatzen der Alten Welt. Akademische Verlagsgesellschaft, Leipzig, Germany. IUCN (2003) 2003 IUCN Red List of Threatened Species. IUCN, Gland, Switzerland [http://www.redlist.org, accessed 27 November 2003]. 
Jacobi, A. (1922) Zoologische Ergebnisse der Walter Stotznerschen Expedition nach Szetschwan, Osttibet and Tschili, auf Grund der Sammlungen und Beobachtungen Dr. Hugo Weigolds, Vol. 2. (Mammalia). Abhandlungen und Bereichte Museum fur Tierkunde und Volkerkunde, Dresden, 16, 9.

Liao, Y. (1985) Preliminary survey of the desert cat in Qinghai. Chinese Zoo Yearbook, 1985, 1-12 [in Chinese].

Liao, Y. (1988) Some biological information about the desert cat in Qinghai. Acta Theriologica Sinica, 8, 128-131 [in Chinese].

Liu, N. (2001) Scientific survey in Dunhuang Natural Reserve. Forestry Publishing House of China, Beijing, China [in Chinese].

Lönnberg, E. (1926) Notes on some cats from eastern Asia with description of a new subgenus. Arkiv för Zoologi, 18 A, 1-22.

Mallon, D. (2002) Manul sighting in Qinghai, China. Cat News, $36,18$.

Matschie, P. (1908) Mammalia. Über chinesische Säugetiere, bosonders aus den Sammlungen des Herren Wilhelm Filchner. In Wissenschaftliche Ergebnisse der Expedition Filchner nach China und Tibet 1903-1905. Vol. 10, pt. I, pp. 134-244, Berlin, Germany.

Milne-Edwards, A. (1892) Observations sur les Mammifères du Thibet. Révue Géneral des Sciences Pûres et Appliqués, 30, 670-672.

Northwest Plateau Institute of Biology (NWIB) (ed.) (1989) Economic Fauna of Qinghai Province. Qinghai People Publishing House, Xining, China [in Chinese].

Nowell, K. \& Jackson, P. (eds) (1996) Wild Cats, Status, Survey and Conservation Action Plan. IUCN/Species Survival Commission Cat Specialist Group, Gland, Switzerland.

Ognev, S.I. (1935) The Mammals of USSR and Adjacent Countries, Vol. III, Carnivora (Fissipedia et Pinnipedia). Glavpushnina NKVT, Moscow, Russia [in Russian].

Pocock, R. I. (1943) Felis bieti vellerosa subsp. nov. Proceedings of the Zoological Society of London, 113B, 172-175.

Pocock, R.I. (1951) Catalogue of the Genus Felis. British Museum (Natural History), London, UK.

Shaanxi Institute of Zoology (ed.) (1974) Rare Economic Mammals in Shaanxi province. Shaanxi Science and Technology Publishing House, Xi'an, China [in Chinese].

Wang, X. (ed.) (1990) Vertebrate Fauna of Ningxia. Ningxia People Publishing House, Yinchuan, China [in Chinese].

Wang, X. (ed) (1991) Vertebrate Fauna of Gansu. Gansu Science and Technology Publishing House, Lanzhou, China [in Chinese].
Wang, X., Qin, C., Jia, W., Song, Z., He, R. \& Zhong, N. (1977) Survey reports about the vertebrates in Ningxia. Journal of Lanzhou University, 1, 110-128 [in Chinese].

Wang, Z. \& Wang, S. (1986) Distribution and recent status of the Felidae in China. In Cats of the World: Biology, Conservation and Management (eds S.D. Miller \& D.D. Everett), pp 201-210. National Wildlife Federation, Washington, DC, USA.

Xinjiang Expedition Team of Chinese Academy of Sciences (1960) Survey Report of Mammals. Unpublished Report, Xinjiang Expedition Team of Chinese Academy of Sciences, Beijing, China [in Chinese].

Yin, B. \& Liu, W. (eds) (1993) Precious and Rare Wildife and its Protection in Tibet. China Forestry Publishing House, Beijing, China [in Chinese].

Zhang, Y.Z. (ed.) (1997) Distribution of Mammalian Species in China. China Forestry Publishing House, Beijing, China [in Chinese].

Zhang, Z.B. \& Wang, Z.W. (eds) (1998) Ecology and Management of Rodent Pests in Agriculture. Ocean Press, Beijing, China [in Chinese].

Zhong, W.Q., Wang, M.J. \& Wan, X.R. (1999) Ecological management of Brandt vole (Microtus brandti) in Inner Mongolia, China. In Ecologically-based Management of Rodent Pests (eds G. R. Singleton, L.A. Hinds, H. Leirs \& Z.B. Zhang), pp 199-214. Australian Centre for International Agricultural Research Monograph, 59.

\section{Biographical sketches}

Li He's research focuses on the ecology and conservation of Chinese endangered species.

Rosa García-Perea is a member of the Cat Specialist Group of the IUCN, and her main research interests are felid systematics, evolution and conservation.

Ming $\mathrm{Li}$ is carrying out research on the conservation genetics of threatened species in China, especially carnivores, primates and ungulates.

Fuwen Wei's main research interests are the behaviour, ecology and conservation biology of threatened species in China, especially giant and red pandas, the Chinese mountain cat, golden monkeys and sika deer and takin. 